\title{
Effects of water glass and DMDHEU treatment on the colonisation of wood by Aureobasidium pullulans
}

\author{
Antje Pfeffer • Andres Dieste • Carsten Mai • \\ Holger Militz
}

Received: 14 September 2009 / Published online: 21 May 2010

(C) The Author(s) 2010. This article is published with open access at Springerlink.com

\begin{abstract}
Specimens of Scots pine sapwood (Pinus sylvestris) and beech (Fagus sylvatica) were treated with a sodium water glass solution and 1,3-dimethylol-4,5-dihydroxyethylene urea (DMDHEU).

The $\mathrm{pH}$-values of water glass treated specimens were between 9.7 and 12.0. Those of DMDHEU treated specimens were 3.8 (Scots pine) and 4.2 (beech).

The resistance observed in an eight weeks laboratory test against the blue stain fungus Aureobasidium pullulans showed that treatments with water glass and DMDHEU reduced but not prevented the fungal growth. Wood specimens treated with water glass showed the lowest colonisation of blue stain. Both treatments inhibited fungal penetration through the ray cells.

HPLC analysis showed that the amount of simple sugars was reduced due to water glass treatment. The amount of simple sugars in DMDHEU treated wood depended on the wood species. The amount of available sugar monomers did not indicate an influence of the colonisation of the sample surface.
\end{abstract}

\section{Die Auswirkung einer Wasserglas und DMDHEU Behandlung auf die Besiedelung von Holz durch Aureobasidium pullulans}

Zusammenfassung Prüfkörper aus Kiefer (Pinus sylvestris) und Buche (Fagus sylvatica) wurden mit Natriumwasserglas und 1,3-dimethylol-4,5-dihydroxyethylene urea (DMDHEU) behandelt.

\footnotetext{
A. Pfeffer $(\bowtie) \cdot$ A. Dieste $\cdot$ C. Mai $\cdot$ H. Militz

Wood Biology and Wood Products,

Georg-August-Universität Göttingen, Göttingen, Germany

e-mail: apfeffe@gwdg.de
}

Die pH-Werte der mit Wasserglas behandelten Prüfkörper lagen zwischen 9,7 und 12,0. Die pH-Werte der mit DMDHEU behandelten Prüfkörper lagen bei 3,8 (Kiefer) und 4,2 (Buche).

Die Resistenz gegen den Bläuepilz Aureobasidium pullulans wurde in einem Laborversuch mit 8 Wochen Versuchsdauer getestet. Die Ergebnisse zeigten, dass die Behandlung mit Natriumwasserglas und DMDHEU den Befall reduzierte, aber nicht verhinderte. Eine radiale Eindringung der Pilzhyphen war makroskopisch nicht sichtbar. Die mit Wasserglas behandelten Prüfkörper zeigten den geringsten Befall auf der Prüfkörperoberfläche.

Die Ergebnisse der HPLC-Analyse zeigten einen reduzierten Gehalt an Einfachzuckern für die mit Wasserglas behandelten Prüfkörper. Bei der DMDHEU-Behandlung war der Gehalt holzartenabhängig. Die Verfügbarkeit von Einfachzuckern hatte demnach keinen Einfluss auf den Befall der Prüfkörperoberfläche.

\section{Introduction}

The damage of wood by fungi is essentially caused by the degradation of the cell wall components by wood decaying fungi, which decrease the structural properties of wood. Wood quality, however, is also influenced by fungal discolouration, particularly blue stain. Blue stain fungi are classified into different groups, blue stain of stems (primary blue stain), blue stain of sawn timber (secondary blue stain) and blue stain in service (tertiary blue stain) (Schmidt 2006). Blue stain is caused by deep and surface colonising fungi. These fungi penetrate into the ray parenchyma in the sapwood parts of wood and utilise easily accessible nutrients, such as sugars, starch, proteins, fats and extractives (Schmidt 2006). The amount of soluble nutrients and their 
accessibility plays an important role for the development of blue stain fungi and their pigment production (Breuil 1997; Carlile et al. 2001). Blue stain fungi do not cause significant mass loss and generally do not affect the structural properties of wood (Liese and Schmid 1961; Grosser 1985; Zink and Fengel 1988; Eaton and Hale 1993). Free water in the lumens of wood cells over longer periods is needed for fungal growth. Therefore, uptake of rain water and sorption of moisture under outdoor weathering conditions are one of the main risk factors of wooden products in service. Blue stain occurs in softwoods such as pine and spruce, but also in hardwoods such as beech and birch. Blue stain in service causes discolourations on wooden products, like wooden facades, window frames and garden furniture. Aureobasidium pullulans is one of the main organisms causing blue stain in service. It is a major coloniser of painted wood and weathered wood surfaces (Sharpe and Dickinson 1992; Schoeman and Dickinson 1997). This fungus causes a black colouration, because of the presence of melanin in the fungal hyphae (Ritsckoff et al. 1998).

To prevent wood in service from blue staining, different strategies have been described. In the last decades very efficient biocidal treatments have been used. In addition to biocide treatments, new strategies for wood protection have been developed in the last years. Compared to biocide treatments these wood modification strategies focus mainly on a change in the material properties of wood to prevent fungal colonisation. One strategy is the reduction of the wood moisture content, because the risk of fungal infection is relatively low if the wood moisture content can be kept below fibre saturation point (Schmidt 2006; Eaton and Hale 1993; Bavendamm 1954). Reduction of the fibre saturation point is achieved through changes of the wood cell wall polymers because of the reaction of the hydroxyl groups with the modification chemical (Papadopoulos and Hill 2002; Hill et al. 2005). Furthermore, wood modification can have an influence on the amount and accessibility of soluble nutrients (Verma et al. 2008) so that it could influence the spore germination and growth of blue stain fungi.

In this study, 1,3-dimethylol-4,5-dihydroxyethylene urea (DMDHEU) and a sodium water glass solution were used for chemical modification. Investigations of wood treated with DMDHEU have been shown to increase the dimensional stability and to decrease moisture uptake of wood (Militz 1993; Yasuda and Minato 1994; Van der Zee et al.
1998; Krause et al. 2003). DMDHEU treatment can also reduce fungal colonisation and mass loss caused by fungal decay (Verma et al. 2008; Xie et al. 2008).

Treatments of wood with water glass solutions have been shown to increase the resistance of the treated wood against brown rot fungi and to decrease fungal colonisation (Dellith 2006).

Investigations about the infestation of modified wood by blue stain fungi and the influence of the ability of simple sugars are limited. Therefore, the objective of this study was to investigate the influence of two different wood modification agents on the development of blue stain and the influence of water soluble sugars in modified wood.

\section{Materials and methods}

\subsection{Treatment of the wood specimens}

Specimens of Scots pine sapwood (Pinus sylvestris L.) and beech (Fagus sylvatica L.) free of knots and cracks with a size of $50 \times 25 \times 15 \mathrm{~mm}^{3}$ (longitudinal $\times$ tangential $\times$ radial) were prepared. Modification chemicals that were used in this study are described in Table 1.

Impregnation of wood specimens was carried out by applying a vacuum of $60 \mathrm{mbar}(60 \mathrm{hPa}, 30 \mathrm{~min})$ and subsequent pressure of $12 \mathrm{bar}(2 \mathrm{~h})$. All treatments were carried out in a laboratory scale process. After impregnation, the water glass treated specimens were stored for three weeks in a desiccator under carbon dioxide atmosphere, which was established by floating the desiccator in regular steps with $\mathrm{CO}_{2}$ from a gas bomb. DMDHEU impregnated specimens were pre-dried at $20^{\circ} \mathrm{C}$ and $65 \% \mathrm{RH}(168 \mathrm{~h})$. Curing of DMDHEU was subsequently performed at $120^{\circ} \mathrm{C}(48 \mathrm{~h})$. The weight percent gain (WPG) of the specimens was determined from the dry masses before and after treatment.

\subsection{Determination of $\mathrm{pH}$-values}

Wood specimens were ground in a disc mill (Retsch, Haan, Germany) to pass a $4 \mathrm{~mm}$ screen. After milling, $5 \mathrm{~g}$ of the wood chips were added to $150 \mathrm{ml}$ cold water. The mixture was shaken for $24 \mathrm{~h}$. The extract was then filtered and $\mathrm{pH}$ of the solution was measured with a glass electrode (Sentix 81, WTW, Weilheim, Germany). The measurements

Table 1 Characterisation of chemicals

Tab. 1 Beschreibung der Chemikalien

\begin{tabular}{lll}
\hline Chemical characterisation & Trade name & Concentration \\
\hline Sodium water glass with additives & BETOL 39 T3 (Woellner, Ludwigshafen, Germany) & 15 wt/wt \\
N-methylol compound, 1,3-dimethylol-4,5-dihydroxyethylene urea & DMDHEU (BASF, Ludwigshafen, Germany) & 1.3 M \\
\hline
\end{tabular}


Table 2 Classification of the blue stain test

Tab. 2 Klassifizierung des Bläuebefalls

\begin{tabular}{ll}
\hline Rating (mean value) & Description \\
\hline 0 & $\begin{array}{l}\text { Not blue stained } \\
\text { Insignificantly blue stained, the surface exhibits only } \\
\text { Individual small blue stained spots with the largest } \\
\text { Diameter of } 2 \text { mm and a maximum of 5\% of the sample surface }\end{array}$ \\
2 & A maximum of 20\% of the surface is blue stained \\
3 & Over 20\% to 50\% of the surface is blue stained \\
4 & Over 50\% to 75\% of the surface is blue stained \\
5 & Strongly blue stained, more than 75\% of the surface \\
\hline
\end{tabular}

Table $3 \mathrm{pH}$-values of treated and untrated wood specimens

Tab. 3 pH-Werte der behandelten und unbehandelten Prüfkörper

\begin{tabular}{lll}
\hline Treatments & pH-values & Beech \\
\hline Untreated & Scots pine & $5.9( \pm 0.2)$ \\
DMDHEU & $5.5( \pm 0.2)$ & $4.2( \pm 0.1)$ \\
Water glass before $\mathrm{CO}_{2}$ storage & $3.8( \pm 0.1)$ & $11.2( \pm 0.3)$ \\
Water glass after $\mathrm{CO}_{2}$ storage & $12.0( \pm 0.1)$ & $9.7( \pm 0.6)$ \\
\hline
\end{tabular}

were performed in two parallel measurements of every sample. Eight samples per treatment were used to determine the $\mathrm{pH}$-values.

\subsection{Blue stain test}

Ten replicates of treated and untreated specimens were sterilised in an autoclave at $121^{\circ} \mathrm{C}(20 \mathrm{~min})$. The sterilised specimens were dipped into a spore suspension of Aureobasidium pullulans (A. pullulans) and placed horizontally in a Kolle flask containing vermiculite which was inoculated with $15 \mathrm{ml}$ of the spore suspension. The incubated specimens were stored in an incubation room at $22^{\circ} \mathrm{C}$ and $70 \%$ RH ( 8 weeks). After incubation the surface was evaluated and ranked from 0 to 5 (Table 2). Two sides of the wood specimens were rated, the side which was in contact with the vermiculite and the reverse side. The blue stained area on the sample surface was calculated using GIMP (GNU Image Manipulation Program, version 2.2.10). Furthermore, the specimens were crosscut $5 \mathrm{~mm}$ from each end in order to assess the penetration of fungal hyphae.

\subsection{Sugar analysis by high pressure liquid chromatography (HPLC)}

Wood specimens were ground in a disc mill (Retsch, Haan, Germany) to pass a $4 \mathrm{~mm}$ screen. After determination of the wood moisture content, $8 \mathrm{~g}$ of wood meal was weighed into folded filter paper. The grounded wood specimens were extracted with $150 \mathrm{ml}$ water in a Soxhlet-extractor for $8 \mathrm{~h}$. The extraction liquid was centrifuged in a laboratory centrifuge (Sigma, Osterode, Germany) at $5000 \mathrm{rpm}$ for $6 \mathrm{~min}$ and the supernatant was decanted. These stock solutions were stored in a refrigerator at $-18^{\circ} \mathrm{C}$ until HPLC analysis.

HPLC was carried out using a binary pump (Waters, Milford, USA) and a refractive index detector (Waters, Milford, USA). A Bio Rad HPX87P column (Bio Rad Germany, München, Germany) and an analytical guard cartridge system (Phenomenex Germany, Aschaffenburg, Germany) are used with water as the mobile phase at an operating temperature of $85^{\circ} \mathrm{C}$ and a flow rate of $0.6 \mathrm{ml} / \mathrm{min}$. Arabinose, fructose, galactose, glucose, xylose and mannose were used as standards. Each treatment was replicated ten times before and after the blue stain test.

Results were statistically analysed by non-parametric one way ANOVA using the Wilcoxon two sample test, because the data were not normally distributed. The comparison between mean values was performed by the Kruskal-Wallis test with a probability level of 0.05 .

\section{Results and discussion}

The DMDHEU treated specimens showed acidic $\mathrm{pH}$-values; the $\mathrm{pH}$-values of water glass treated samples were heavy alkaline (Table 3). 
Table 4 Area of blue stain on the surface of the specimens

Tab. 4 Verblauung der Prüfkörperoberfläche

\begin{tabular}{llll}
\hline Treatments & $\begin{array}{l}\text { Mean value and standard deviation of blue stain } \\
\text { on the surface in contact with vermiculite [\%] }\end{array}$ & Beech & $\begin{array}{l}\text { Mean value and standard deviation } \\
\text { of blue stain on the reverse surface [\%] }\end{array}$ \\
\cline { 2 - 3 } & Scots pine & $77( \pm 9)$ & Scots pine \\
\hline Untreated & $89( \pm 5)$ & $43( \pm 4)$ & $60( \pm 4)$ \\
DMDHEU & $49( \pm 6)$ & $15( \pm 4)$ & $4( \pm 1)$ \\
Water glass & $2( \pm 2)$ & $1( \pm 1)$ & $8( \pm 3)$ \\
\hline
\end{tabular}

Table 5 Classification after blue stain test

Tab. 5 Klassifizierung des Befalls nach dem Bläuetest

\begin{tabular}{|c|c|c|c|c|}
\hline \multirow[t]{2}{*}{ Treatments } & \multicolumn{2}{|c|}{$\begin{array}{l}\text { Classification of the surface } \\
\text { in contact with vermiculite }\end{array}$} & \multicolumn{2}{|c|}{ Classification of the reverse surface } \\
\hline & Scots pine & Beech & Scots pine & Beech \\
\hline Untreated & 5 & 5 & 4 & 4 \\
\hline DMDHEU & 3 & 3 & 1 & 2 \\
\hline Water glass & 1 & 2 & 1 & 1 \\
\hline
\end{tabular}

Table 6 Mean value and standard deviation of the sugar content before and after blue stain test, specimens of Scots pine sapwood

Tab. 6 Mittelwert und Standardabweichung des Zuckergehaltes vor und nach Bläuetest, Prüfkörper aus Kiefernsplintholz

\begin{tabular}{|c|c|c|c|c|c|c|}
\hline & \multicolumn{2}{|c|}{$\begin{array}{l}\text { Untreated } \\
\text { [mg/g dry wood] }\end{array}$} & \multicolumn{2}{|c|}{$\begin{array}{l}\text { DMDHEU } \\
\text { [mg/g dry wood] }\end{array}$} & \multicolumn{2}{|c|}{$\begin{array}{l}\text { Water glass } \\
\text { [mg/g dry wood] }\end{array}$} \\
\hline & Before test & After test & Before test & After test & Before test & After test \\
\hline Arabinose & $\mathrm{nq}$ & $\mathrm{nq}$ & $2.28( \pm 0.02)$ & $1.78( \pm 0,77)^{*}$ & $\mathrm{nq}$ & $\mathrm{nq}$ \\
\hline Fructose & $\mathrm{nq}$ & $0.23( \pm 0.13)$ & $\mathrm{nq}$ & $\mathrm{nq}$ & $\mathrm{nq}$ & $\mathrm{nq}$ \\
\hline Galactose & $1.09( \pm 0.03)$ & $1.34( \pm 0.23)^{*}$ & $12.90( \pm 0.42)$ & $8.99( \pm 0,34)^{*}$ & $\mathrm{nq}$ & $\mathrm{nq}$ \\
\hline Glucose & nq & $\mathrm{nq}$ & $11.09( \pm 3.62)$ & $1.95( \pm 0,96)^{*}$ & $\mathrm{nq}$ & $\mathrm{nq}$ \\
\hline Xylose & $0.04( \pm 0.02)$ & $\mathrm{nq}$ & $9.92( \pm 0.17)$ & $\mathrm{nq}^{*}$ & $\mathrm{nq}$ & $\mathrm{nq}$ \\
\hline Mannose & $4.29( \pm 0.04)$ & $\mathrm{nq}^{*}$ & $\mathrm{nq}$ & $\mathrm{nq}$ & $3.73( \pm 0.03)$ & $3.98^{*}( \pm 0.19)$ \\
\hline Total amount & $5.42( \pm 0.09)$ & $1.57( \pm 0.36)$ & $36.19( \pm 4.23)$ & $12.72( \pm 2.27)$ & $3.73( \pm 0.03)$ & $3.98( \pm 0.19)$ \\
\hline
\end{tabular}

nq: not quantified, the amount was below the detection limit of the base line

*Indicates a significant difference at the 0.05 level (Kruskal-Wallis test)

After eight weeks of incubation all specimens were blue stained. In all cases the surfaces which were in contact with the vermiculite showed more stained area than the reverse surfaces of the specimens (Tables 4 and 5). Wood specimens treated with water glass showed the lowest degree of colonisation. The treatment with DMDHEU also reduced fungal growth but did not prevent it.

The simple sugar contents of untreated and treated specimens of Scots pine sapwood and Beech wood before and after the infestation of blue stain is shown in Tables 6 and 7.

\subsection{Untreated wood specimens}

The untreated specimens displayed the highest infection of blue stain on the surfaces and after cross cutting. The fungal growth started from the surface in contact with the vermiculite and penetrated through the ray cells. The staining of the reverse surface of untreated specimens was caused by the radial penetration of the hyphae from the surface in contact with the vermiculite to the reverse side. Additionally it was caused by spore germination and hyphae growth directly on the reverse surface. 
Table 7 Mean value and standard deviation of the sugar content before and after blue stain test, beech samples Tab. 7 Mittelwert und Standardabweichung des Zuckergehaltes vor und nach Bläuetest, Prüfkörper aus Buche

\begin{tabular}{|c|c|c|c|c|c|c|}
\hline & \multicolumn{2}{|c|}{$\begin{array}{l}\text { Untreated }[\mathrm{mg} / \mathrm{g} \\
\text { dry wood] }\end{array}$} & \multicolumn{2}{|c|}{$\begin{array}{l}\text { DMDHEU }[\mathrm{mg} / \mathrm{g} \\
\text { dry wood] }\end{array}$} & \multicolumn{2}{|c|}{$\begin{array}{l}\text { Water glass } \\
\text { [mg/g dry wood] }\end{array}$} \\
\hline & Before test & After test & Before test & After test & Before test & After test \\
\hline Fructose & $3.87( \pm 1.11)$ & $\mathrm{nq}^{*}$ & $\mathrm{nq}$ & $\mathrm{nq}$ & $\mathrm{nq}$ & $\mathrm{nq}$ \\
\hline Galactose & $1.02( \pm 0.01)$ & $1.64( \pm 0.05)^{*}$ & $9.80( \pm 1.07)$ & $13.13( \pm 0,93)^{*}$ & $1.56( \pm 0.05)$ & $2.14 *( \pm 0.20)$ \\
\hline Glucose & $4.33( \pm 1.59)$ & $\mathrm{nq}^{*}$ & $\mathrm{nq}$ & $\mathrm{nq}$ & $\mathrm{nq}$ & $\mathrm{nq}$ \\
\hline Mannose & $3.97( \pm 0.03)$ & $\mathrm{nq}^{*}$ & $\mathrm{nq}$ & nq & $3.89( \pm 0.03)$ & $4.19^{*}( \pm 0.06)$ \\
\hline Total amount & $13.19( \pm 2.74)$ & $\mathbf{1 . 6 4}( \pm 0.05)$ & $9.80( \pm 1.07)$ & $13.13( \pm 0.93)$ & $\mathbf{5 . 4 5}( \pm 0.08)$ & $\mathbf{6 . 3 3}( \pm 0.26)$ \\
\hline
\end{tabular}

nq: not quantified, the amount was below the detection limit of the base line

Arabinose and xylose were not determined

*Indicates a significant difference at the 0.05 level (Kruskal-Wallis test)

The untreated specimens of beech indicated a higher amount of water soluble carbohydrates than Scots pine sapwood. Willför et al. (2005a, 2005b) showed a total amount of water soluble carbohydrates from different pine species (sapwood) between 4.6 and $6.9 \mathrm{mg} / \mathrm{g}$ dry wood and from beech $12.5 \mathrm{mg} / \mathrm{g}$ dry wood including dissolved acidic sugar units. After the blue stain test the amount of sugars decreased in untreated wood. Mannose was the most reduced monosaccharide independent of the wood species. It could not be quantified after the blue stain test (Tables 6 and 7) and appeared to be mostly utilised by A. pullulans in untreated wood specimens.

In beech specimens also glucose and fructose were reduced. Fleet et al. (2001) showed similar results for different sapstaining fungi on lodgepole pine (Pinus contorta Dougl. ex Loud.), with mannose and glucose as the most reduced sugars after fungal infection. These results indicated a preference for mannose by A. pullulans in untreated Scots pine and beech wood. The specimens showed a significantly higher level of galactose after the blue stain test. Galactose appeared not to be utilised by A. pullulans and other sapstaining fungi (Fleet et al. 2001), but glucose, glucuronic acid and also galactose and mannose were detected on cell walls of A. pullulans (Bernier 1958; Brown et al. 1973).

\subsection{Water glass treated wood specimens}

In case of the water glass treated specimens the amount of monosaccharides was low and only mannose (Scots pine sapwood) and galactose and mannose (beech) showed a significant level after the treatment. The simple sugars can be washed out during impregnation, because of the high water solubility of sugars in alkaline solutions.

A radial penetration of fungal hyphae was not visible, only a fungal infestation on the wood surfaces. The discolouration of both surfaces might be caused only by spore germination and hyphae growth directly on these surfaces. Fungal tests of water glass treated wood are difficult to carry out because of the high amounts of leaching chemicals and the high moisture content of wood specimens during fungal incubation (Furuno et al. 1991, 1992; Furuno and Imamura 1998). The main effect which might be responsible for the reduction of blue stain is the highly alkaline $\mathrm{pH}$-value and the high wood moisture content of the specimens. A secondary effect is the formation of insoluble silicates, which are mainly located in the cell lumens (Furuno et al. 1992).

The water glass treated specimens showed a highly alkaline $\mathrm{pH}$-value before and after storage under carbon dioxide atmosphere. Before carbon dioxide treatment the $\mathrm{pH}$ value was high due to the alkaline waterglass solution. After carbon dioxide treatment, the resulted sodium carbonate on the sample surface and the alkaline parts of the silicates caused high $\mathrm{pH}$ values. The $\mathrm{pH}$-value for growth of A. pullulans is between 3.5 and 6.3 (McNeil et al. 1989) so that the highly alkaline $\mathrm{pH}$ values can influence spore germination, mycelia growth and fruit body formation (Schmidt 2006; Reiß 1997). Sodium carbonate forms an alkaline solution in the presence of water (wetted vermiculite) which could influence the spore germination and mycelia growth in the surrounding area of the sample. Investigations of Dellith (2006) also reported a high resistance of water glass treated specimens against wood destroying basidiomycetes, because of the high pH-values and the insoluble silicates in the cell lumens (Furuno et al. 1992). The moisture content of water glass treated specimens was high (mean 108\%), indicating hygroscopicity of unreacted silicates and sodium carbonate on the sample surface.

\subsection{DMDHEU treated specimens}

The surface discolouration of DMDHEU treated specimens was reduced compared to untreated specimens and no radial 
penetration of fungal hyphae was visible. The discolouration of both surfaces might be caused only by spore germination and hyphal growth directly on these surfaces. The $\mathrm{pH}$-values were acidic. The content and composition of monosaccharides in DMDHEU treated specimens were different from untreated wood and dependent on hard- and softwood species. Scots pine samples treated with DMDHEU showed a significantly higher amount $(36.1 \mathrm{mg} / \mathrm{g}$ dry wood) of total simple sugars as compared to untreated wood (5.4 $\mathrm{mg} / \mathrm{g}$ dry wood). After eight weeks of incubation with $A$. pullulans the amount of sugar was reduced. The percentage reduction of simple sugars in DMDHEU treated samples (65\%) was comparable to the one of untreated Scots pine specimens $(71 \%)$. The amount of simple sugars in DMDHEU treated Beech wood $(9.8 \mathrm{mg} / \mathrm{g}$ dry wood) was significantly lower than in treated Scots pine $(36.2 \mathrm{mg} / \mathrm{g}$ dry wood). Independent of the amount of simple sugars there was only a negligible difference in the percentage surface discolouration of DMDHEU treated beech and Scots pine sapwood. These results indicated that the amount of available sugar monomers does not directly influence the degree of colonisation of the sample surface of DMDHEU treated wood. Other factors caused by modification with DMDHEU might have a higher influence on the fungal colonisation, such as wood moisture content and physical blocking of the penetration pathways of fungal hyphae (Xie et al. 2008). At wood moisture contents close to fibre saturation point DMDHEU modified wood absorbs less water molecules than unmodified wood (Krause et al. 2003; Dieste et al. 2008) and the treatment reduces the speed of liquid water uptake caused by the inclusion of the molecule in the ray cells, the major penetration pathways for water in untreated wood (Xie 2005; Xie et al. 2008). The moisture content is high enough for fungal infestation particularly on the sample surface which is in contact with the wetted vermiculite, because of the higher moisture content at the interface of wood and vermiculite. But the wood moisture content might not be adequate in the inner part of the specimen for fungal growth. The main penetration pathways for fungal hyphae are the ray cells, which are also the main penetration paths of impregnation liquids (Sell 1977). Both could be physically restricted, because of the deposition of DMDHEU molecules within the cell walls and cell lumens.

Further investigations are required to obtain more detailed information on the inhibition factors of modified wood against blue stain for further improvement of modification methods against staining fungi. The differences in the content and composition of simple sugars in DMDHEU treated wood depending on hard- and softwood species are still unclear. Therefore, more detailed studies are necessary to clarify the influence of DMDHEU treatment on the content and composition of simple sugars depending on hard- and softwood species.

\section{Conclusion}

Treatments with a sodium water glass solution and DMDHEU reduced but not prevented fungal growth compared to untreated wood. The results of HPLC analysis of simple sugars showed that the amount of available sugar monomers did not indicate an influence of the colonisation of the sample surface.

Depending on the treatment further factors might have an influence on the fungal colonisation, such as $\mathrm{pH}$-value, wood moisture content and physical blocking of the penetration pathways of fungal hyphae.

Acknowledgement We thank the "Deutsche Bundesstiftung Umwelt" (DBU) for granting Antje Pfeffer a doctoral scholarship.

Open Access This article is distributed under the terms of the Creative Commons Attribution Noncommercial License which permits any noncommercial use, distribution, and reproduction in any medium, provided the original author(s) and source are credited.

\section{References}

Bavendamm W (1954) Bläuepilze. Holz Roh- Werkst 12:205-208

Bernier B (1958) The production of polysaccharides by fungi active in the decomposition of wood and forest litter. Can J Microbiol 4:195-204

Breuil C (1997) Wood as nutritional resource for staining fungi. In: Morrell JJ, Dickinson D (eds) Biology and prevention of sapstain. Proceedings of conference, Whistler, Canada. Forest Products Society, Madison, pp 1-5. Publication no. 7273

Brown RG, Hanic LA, Hsiao M (1973) Structure and chemical composition of yeast chlamydospores of Aureobasidium pullulans. Can J Microbiol 19:163-168

Carlile MJ, Watkinson SC, Gooday GW (2001) The fungi. Academic Press, London

Dellith W (2006) Beitrag zum alternativen Holzschutz durch modifizierte Alkalisilikatlösungen als Schutzmittel gegenüber holzzerstörenden Pilzen und Insekten. Dissertation, Bauhaus-Universität Weimar, Fakultät für Bauingenieurwesen

Dieste A, Krause A, Militz H (2008) Modification of Fagus sylvatica with 1,3-dimethylol-4,5-dihydroxy ethylene urea (DMDHEU). Part 1: Estimation of heat of adsorption by the isosteric method (Hailwoood-Horrobin model) and by solution calorimetry. Holzforschung 62:577-583

Eaton RA, Hale MDC (1993) Wood-decay, pests and protection. Chapman \& Hall, London

Fleet C, Breuil C, Uzunovic A (2001) Nutrient consumption and pigmentation of deep and surface colonizing sapstain fungi in Pinus contorta. Holzforschung 55:340-346

Furuno T, Uehara T, Jodai S (1991) Combinations of wood and silicate. Part 1: Impregnation by water glass and applications of aluminium sulfate and calcium chloride as reactants. Mokuzai Gakkaishi 37:462-472

Furuno T, Shimada K, Uehara T, Jodai S (1992) Combinations of wood and silicate. Part 2: Woodmineral composites using water glass and reactance of barium chloride, boric acid and borax and their properties. Mokuzai Gakkaishi 38:448-457

Furuno T, Imamura Y (1998) Combinations of wood and silicate. Part 6: Biological resistances of wood-mineral composites using water glass-boron compound system. Wood Sci Technol 32:161170 
Grosser D (1985) Pflanzliche und tierische Bau- und Werkholzschädlinge. DRW-Verlag, Leinfelden-Echterdingen

Hill CAS, Forster SC, Farahani MRM, Hale MDC, Ormondroyd GA, Williams GR (2005) An investigation of cell wall micropore blocking as a possible mechanism for the decay resistance of anhydride modified wood. Int Biodet Biodeg 55:69-76

Krause A, Jones D, Van der Zee ME, Militz H (2003) Interlace treatment-wood modification with N-methylol compounds. In: Van Acker J, Hill CAS (eds) Proceedings of the first European conference on wood modification, Ghent, Belgium, pp 317-327

Liese W, Schmid R (1961) Licht- und elektronenmikroskopische Untersuchungen über das Wachstum von Bläuepilzen in Kiefern- und Fichtenholz. Holz Roh- Werkst 19:329-337

McNeil B, Kristiansen B, Seviour RJ (1989) Polysaccharide production and morphology of Aureobasidium pullulans in continuous culture. Biotechnol Bioeng 33:1210-1212

Militz H (1993) Treatment of timber with water-soluble dimethylol resin to improve their dimensional stability and durability. Wood Sci Technol 27:347-355

Papadopoulos AN, Hill CAS (2002) The biological effectiveness of wood modified with linear chain carboxylic acid anhydrides against Coniophora puteana. Holz Roh- Werkst 60:329-332

Reiß J (1997) Schimmelpilze. Lebensweise, Nutzen, Schaden, Bekämpfung. Springer, Berlin

Ritsckoff A-C, Rättö M, Thomassin F (1998) Influence of the nutritional elements on pigmentation and production of biomass of bluestain fungus Aureobasidium pullulans. In: Morrell JJ, Dickinson DJ (eds) Proceedings of the sapstain symposium—biology and prevention of sapstain. Forest Products Society, Madison, pp $7-10$

Sell J (1977) Hydrophobierende Holzimprägnierung - Wirkungsweise, Eigenschaften, Anwendungsmöglichkeiten. Holz Roh- Werkst $35: 75-78$

Schmidt O (2006) Wood and tree fungi. Springer, Berlin

Schoeman M, Dickinson DJ (1997) Growth of Aureobasidium pullulans on lignin breakdown products at weathered wood surfaces. Mycologist 11:168-172
Sharpe PR, Dickinson DJ (1992) Blue stain in service on wood surface coatings. Part 2: The ability of Aureobasidium pullulans to penetrate wood surface coatings. Document No.: IRG/WP/1557-92. The International Research Group on Wood Preservation, Stockholm

Van der Zee ME, Beckers EPJ, Militz H (1998) Influence of concentration, catalyst and temperature on dimensional stability of DMDHEU modified Scots pine. Document No.: IRG/WP/9840119. The International Research Group on Wood Preservation, Stockholm

Verma P, Dyckmans J, Militz H, Mai C (2008) Determination of fungal activity in modified wood by means of micro-calorimetry and determination of total esterase activity. Appl Microbiol Biotechnol 80:125-133

Willför S, Sundberg A, Hemming J, Holmbom B (2005a) Polysaccharides in some industrially important softwood species. Wood Sci Technol 39:245-258

Willför S, Sundberg A, Pranovich A, Holmbom B (2005b) Polysaccharides in some industrially important hardwood species. Wood Sci Technol 39:601-617

Yasuda R, Minato K (1994) Chemical modification of wood by nonformaldehyde cross linking reagents. Part 1 . Improvement of dimensional stability and acoustic properties. Wood Sci Technol 27:287-293

Xie Y (2005) Surface properties of wood modified with cyclic $\mathrm{N}$-methylol compounds. PhD thesis. University of Göttingen, Institute of Wood Biology and Wood Technology

Xie Y, Krause A, Militz H, Mai C (2008) Weathering of uncoated and coated wood treated with methylated 1,3-dimethylol4,5-dihydroxyethyleneurea (mDMDHEU). Holz Roh- Werkst 66:455-464

Zink P, Fengel D (1988) Studies on the colouring matter of blue-stain fungi. Part 1: General characterisation and the associated compounds. Holzforschung 42:217-220 